\title{
MEETING THE INFORMATION NEEDS OF GHANAIAN COCOA FARMERS: ARE FARMER FIELD SCHOOLS THE ANSWER?
}

\author{
F. Baah \\ Social Science and Statistics Unit, \\ Cocoa Research Institute of Ghana, \\ P.O Box 8, Tafo-Akim, Ghana
}

\begin{abstract}
A number of farmer-led approaches to technology transfer have emerged in recent times to replace the largely discredited Transfer of Technology (TOT) and Training and Visit (T\&V) models of agricultural extension. One such initiative is the Farmer Field School (FFS), an experiential learning approach originally developed in Southeast Asia for the integrated management of rice pests but adaptable to other crops and even to livestock and fisheries. The experiences in the use of FFS in other crops have been applied to cocoa in studies in the Central and Ashanti regions of Ghana. This study used a mixed method of group interviews, questionnaire survey and in-depth one-on-one interviews to elicit information from farmers in Atwima and Amansie-West districts of Ashanti where the sustainable tree crops programme (STCP) has been conducting FFSs since 2002, with the object of evaluating the extent to which the FFS approach could augment existing extension strategies in meeting farmers' information needs. The sample included participants and non-participants alike providing a basis for comparative analysis. The results indicate that majority of the farmers (70\%) rely on their social networks of friends, neighbours and family members for information and advice with only 13\% regarding extension agents as their main source of advice. No significant differences $(P<0.05)$ were found between FFS farmers and non-FFS farmers in terms of output, awareness or attitudes but FFS farmers undertook more of some production practices on their farm. The implications of these and other findings are discussed in relation to the quest for participatory modes of information sharing within the cocoa knowledge and information system.

\section{INTRODUCTION}

Agricultural extension as an activity has been used as an instrument to induce change in agricultural communities over the years. The transfer of technology (ToT) model of agricultural extension by which technological innovations

are transferred from research to farmers via extension agents has been the dominant mode of information transfer until quite recently. It is now largely acknowledged that farmers are not merely passive receivers of the ideas of scientists; they are active researchers and experimenters them-
\end{abstract}


selves (Röling, 1994). This has led to the movement towards stronger participation by farmers in agricultural research and extension fuelled by the growing realization that the socio-economic and agro-ecological conditions of farmers are complex, diverse and risk-prone, and that conventional approaches such as the ToT model are unlikely to be fruitful (Farrington, 1998).

A number of participatory approaches have been adopted in the past by national and international agricultural research and extension systems to involve farmers in the research and technology dissemination processes. These include, farming systems research and extension (Simmonds, 1986; Wiggins, 1995; Jiggins, 1981; Chambers, 1980, 1986; Tripp, 1989; Biggs, 1984), farmer participatory research (Okali et al, 1994; Tripp, 1989; Sumberg and Okali, 1988; Richards, 1986) and the farmer first and last (FFL) model (Chambers and Ghildyal, 1985). Each approach has had its fair share of criticisms (Baah, 2001a). The consensus appears that these approaches have not integrated and empowered farmers enough for them to reap the benefits of the technology development and dissemination processes. Farmer Field Schools (FFS) appears to be one strategy that has won the hearts of farmers and development workers alike.

\section{Farmer Field Schools (FFS)}

The FFS training methodology is said to have originated from the FAO intercountry programme in Asia where it has been used to train over one million farmers (Afreh-Nuamah, 1999). The FAO launched an Integrated Pest Management (IPM) programme in irrigated rice in seven Southeast Asian countries in 1979 (Bruin and Meerman, 2001). Initially, the extension approach used was the top-down transfer of technology methodology. This did not work and was replaced with a model in which groups of farmers were trained during a season-long activity. This approach was called the Farmer Field School (van de Fliert, Pontius and Röling, 1995). The FFS has proven to be a very effective tool for cultivating farmer learning and empowerment and helping farmers to develop their critical thinking. A FFS is organized by a facilitator who does not act as a teacher but facilitates a learning process. Farmers meet during the cropping season in groups at a location close to a field of study.

The following important IPM principles underlie the FFS training programme (Bruin and Meerman, 2001; van de Fliert et al., 1995):

1. Growing a healthy crop. This involves proper crop and plant management practices, which allow the plant to recover better from environmental or pest injury.

2. Observe field (crops) regularly. The Agroecosystem Analysis (AESA) is the FFS's core activity and sharpens farmers' skills in the areas of observation and decisionmaking. Informed decision-making enables appropriate interventions to be made quickly for water, soil and plant management

3. Conserve natural enemies. This provides for biological control of pests and diseases by parasites, predators and pathogens.

4. Farmers become experts. Farmers acquire the basic understanding of the agroecological system and decision-making processes and this is important for long-term management of soils, pests and crops.

According to Gallagher (2003), the basic format of an IPM Farmer Field School consists of three activities: agro-ecosystem observation, analysis and presentation of results; a special topic and a group dynamics activity. The AESA is the FFS's core activity and other activities are designed to support it. A table of activities undertaken in a FFS session is shown below:

The FFS may be adapted to any crop. However, the process must be learner-centred, participatory and rely on the experiential learning approach taking into consideration the key growth stages of the crop, local cropping patterns and specific local problems (Pontius, Dilts and Barlett, 2002).

164 Journal of Science and Technology, Vol. 27, No. 3, December 2007 
Table 1: An FES session in the original Indonesian setting

\begin{tabular}{|c|c|}
\hline Time & Activity \\
\hline 8.00 a.m. & $\begin{array}{l}\text { Opening (offen with prayer) } \\
\text { Attendance call } \\
\text { Briefing of day's activities } \\
\text { Stretching exercises }\end{array}$ \\
\hline 8.30 a.m. & Field activities in small groups with facilitator (AESA) \\
\hline 9.30 a.m. & $\begin{array}{l}\text { Return to shade, AESA drawings and discussion of } \\
\text { management decisions }\end{array}$ \\
\hline 10.15 a.m. & Group presentation of results and discussion \\
\hline 11.00 a.m. & Short tea/coffee/water break \\
\hline 11.15 a.m. & Energiser or group building exercise \\
\hline 11.30 a.m. & Special topic \\
\hline 12.30 p.m. & Closing (often with prayer) \\
\hline
\end{tabular}

Source: Gallagher (2003)

The discovery learning approach in FFS, which emphasizes the uniqueness of the individual's experience of reality (Pretty, 1995) has attracted the attention of researchers who are keen to emphasize the move away from directive extension towards approaches that foster participation, self-confidence, dialogue, joint decision-making and self-determination. This has been suggested as a necessary condition for sustainable agriculture which is knowledge intensive and requires that large numbers of farming households must be motivated to use coordinated resource management (Röling and Pretty, 1997; van de Fliert, 2003).

\section{IPM/FFS in Ghana}

The use of IPM/FFS as extension strategy in Ghana commenced in 1995 through the FAO/ UNDP funded National Poverty Reduction Programme (NPRP) at the Dawhenya Irrigation Project with 28 field extension personnel. The success of the Dawhenya Training of Trainers (TOT) programme led to follow-up training programmes for rice farmers at five irrigation sites (Ashaiman, Dawhenya, Afife, Botanga and Tono). About 500 rice farmers were trained under this programme (Afreh-Nuamah, op. cit.).
Farmers involved in the training became better managers of their rice fields. They obtained higher yields (over $100 \%$ compared to their untrained neighbours). Over $80 \%$ of the farmers changed their practices and adopted IPM strategies. Some of them became trainers imparting their new skills to other farmers. According to Afreh-Nuamah (op.cit.), the outcome of the programme convinced the relevant government authorities that the IPM/FFS strategy could complement existing extension strategies and increase farmers' incomes. Consequently, funding was provided for further training of 1700 rice, vegetables and plantain farmers in five districts. At the close of 1999, over 1000 farmers had received training (Table 2).

\section{IPM/FFS in Ghana Cocoa Industry}

Cocoa remains an important sector in the Ghanaian economy contributing 4.35 to agricultural GDP in 2004 (ISSER, 2005). Disparities between yields obtained on research station and farmers' farms remain a major concern. Recent efforts to increase yields on farmers' farms include the national control of cocoa pests and diseases and increase in producer price paid to farmers. Extension remains the key instrument of transfer of research results to farmers. The use of a multi- 
Table 2: Numbers of Farmers Trained in IPM/FFS (NPRP)

\begin{tabular}{lccc}
\hline District & Rice & $\begin{array}{c}\text { Cropping System } \\
\text { Vegetables }\end{array}$ & Plantain \\
\hline Bongo & 210 & 60 & - \\
Dangme West & 190 & 90 & - \\
Afram Plains & 60 & 60 & - \\
Weija (Accra) & - & 240 & - \\
Juabeso-Bia & 60 & 60 & 84 \\
Total & 520 & 510 & 84 \\
\hline
\end{tabular}

Source: Afreh-Nuamah (1999)

plicity of approaches to tackle the main problems of pests and diseases afflicting cocoa in Ghana has a long history. Scientists at the Cocoa Research Institute of Ghana (CRIG) have employed chemical, biological and cultural methods to control cocoa pests. On-farm studies are important components of these efforts. CRIG collaborated with Conservation International, an international non-governmental organization, the national Integrated Crop and Pest Management (ICPM) unit of the Ministry of Food and Agriculture (MOFA) to incorporate IPM/FFS strategies in cocoa production.

An important objective of this initiative was to use the FFS to transfer cocoa production technologies to farmers, and consequently increase their income. Communities around the Kakum National Park in the Central Region were chosen for the pilot phase. For these communities, another expected benefit of the intervention was that with increased income from cocoa (on existing unit areas), the farmers would be less inclined to encroach on the forest reserve. The project commenced in March 2001 and ended late 2003 and reviews are provided in Baah et al. (2003) and Osei-Bonsu et al. (2003). Following the perceived success of the Kakum study, USAID $^{1}$ provided funds through the Sustainable Tree Crops Programme (STCP) for its extension in the Atwima and Amansie West districts of

${ }^{1}$ United States Agency for International Development
Ashanti region. This programme commenced in 2003 and is on-going and is the focus of this study which had the main objective of evaluating the extent to which the FFS approach could augment existing extension strategies in meeting farmers' information needs.

\section{MATERIALS AND METHODS}

A mixed method approach (Neuman, 2003) involving the use of focus group discussions, questionnaire survey and in-depth interviews was used to elicit information from farmers. Twenty-five focus group discussions were followed by the administration of questionnaires on 278 randomly selected cocoa farmers using a two-stage stratified sampling procedure, the sample size being determined by procedures suggested by Casley and Kumar (1989). After the questionnaire survey, 10 farmers were purposively selected and interviewed for further clarification and insight. The study was carried out in ten villages (the questionnaire survey in 5) in Atwima (Akorabuorkrom, Otaakrom, Kyereyaaso, Amadaa and Aweafutu) and Amansie West (Esaase, Aboabotetekaso, Tetrem, Ahwerewa and Kobeng) districts of Ashanti Region, Ghana between November 2004 and May 2005. The quantitative and qualitative data were analyzed using the statistical software for the social sciences (SPSS version 11.5) and Nudist (version 12) respectively.

166 Journal of Science and Technology, Vol. 27, No. 3, December 2007 
RESULTS

\section{Sample Characteristics}

Studies have shown that cocoa farmer characteristics such as age, marital status, number of children and level of education have a bearing on farm management behaviour and decision making processes (such as adoption), and hence agricultural output (Donkor, Henderson and Jones, 1991; Boahene, 1995). The sample was 'gender sensitive' in that both sexes were fairly represented (Table 3). Majority of the farmers were married $(79 \%)$ with a mean of 9 (the median and mode were 6) children.
Over half the sample (56\%) was aged 50 years and above, reflecting the ageing nature of Ghanaian cocoa farming population (Table 3 ). In terms of education, majority $(66 \%)$ had some form of education ranging from the basic primary education to college or university. Gender correlated positively and significantly $(\mathrm{P}<0.01)$ with education (Cramer's $\mathrm{V}=0.316, \mathrm{P}=0.000$ ) and the differences between men and women were significant $\left(\chi^{2}=55.653\right.$, df $\left.=10, \mathrm{P}<0.01\right)$. Age also showed a positive correlation with level of education (Cramer's $\mathrm{V}=0.358, \mathrm{P}<0.001$ ).

Table 3: Personal Characteristics of Sample

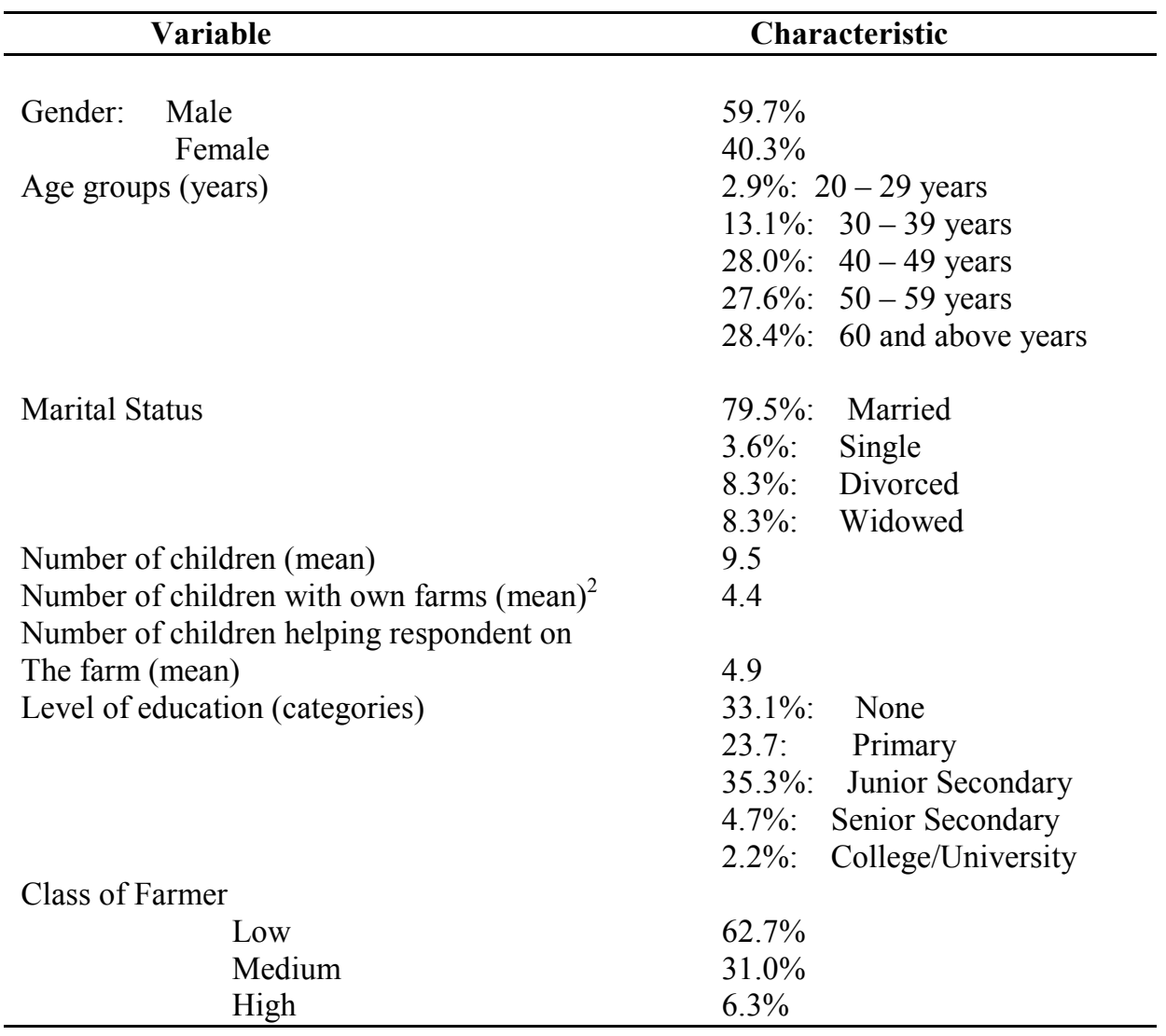

Source: Survey data. Percentages may not add up to 100 because of non-response 


\section{Socio-economic Characteristics}

Majority of the farmers (64\%) had been in cocoa cultivation for 10 years or more (Table 2) with $15 \%$ belonging to a farmer association. Farming experience showed a positive correlation with membership of farmer association (Cramer's V $=0.195, \mathrm{P}<0.001$ ). Cocoa farmers could be classified into 3 production classes: low class farmers, medium class and high class on the basis of their level of management and ultimately, yield (see FAO/World Bank, 1986). In this sample, $62.7 \%$ were low class, $31.0 \%$ medium and only $6.3 \%$ in the high class category (Table 3 ). Class of farmer correlated positively with level of education (Cramer's V $=0.298, \mathrm{P}<0.001$ ) and farming experience (Cramer's V $=0.224, \mathrm{P}<0.001$ ).

Mean total land available to farmers was 14.7 ha with 8.4 ha being under cocoa from which the farmers obtain an average yield of $111.4 \mathrm{~kg} / \mathrm{ha}$ dry beans. This was quite lower than the 250$350 \mathrm{~kg} / \mathrm{ha}$ often reported (e.g., FAO/World Bank,
1986; MASDAR, 1998; Donkor et al, 1991; Appiah, 2004), and represents $69.31 \%$ of their annual income with the rest coming from food crops and non-farming activities including petty trading. Highly significant differences were found between gender and yield $(\mathrm{t}=3.138, \mathrm{df}=271, \mathrm{P}$ $=0.002)$ and between class of farmer and yield $(\mathrm{kg} / \mathrm{ha})(\mathrm{F}=11.315, \mathrm{P}=0.000)$.

\section{FFS and Non-FFS farmers compared}

Because the FFS was meant to raise farmers' awareness and knowledge of practices associated with cocoa cultivation, attempts were made to find out if they fared better in these matters compared to non-participating farmers.

In terms of awareness, respondents were asked a number of questions related to cocoa research recommendations made by CRIG (see table 5 for list of CRIG ${ }^{2}$ recommendations). Their responses were then summed into an 'awareness index'. Using the t-test for independent samples, no sig-

Table 4: CRIG Innovations/ Recommended Technologies for Cocoa

\begin{tabular}{|c|c|}
\hline Common practice and yield & improved practice and yield \\
\hline $\begin{array}{l}\text { Heavy uncontrolled shade and lack of Regular } \\
\text { maintenance on small farms } 212 \mathrm{~kg} / \mathrm{ha}\end{array}$ & $\begin{array}{l}\text { Medium shade, well maintained. Yield, } 700 \mathrm{~kg} / \mathrm{ha} \text { dry } \\
\text { beans. }\end{array}$ \\
\hline Shade with regular maintenance. $656 \mathrm{~kg} / \mathrm{ha}$. & No shade, regular maintenance. \\
\hline $\begin{array}{l}\text { No pruning, but regular maintenance. } 693 \mathrm{~kg} / \mathrm{ha} \text {. } \\
\text { Shade, No fertilizer, but regular Maintenance. } \\
952 \mathrm{~kg} / \mathrm{ha}\end{array}$ & $\begin{array}{l}\text { Pruning. } 1164 \mathrm{~kg} / \mathrm{ha} \\
\text { No shade plus fertilizer. } 3.5 \text { tons } / \mathrm{ha}\end{array}$ \\
\hline No insecticide. $445 \mathrm{~kg} / \mathrm{ha}$. & $\begin{array}{l}\text { Insecticide application, } 380 \mathrm{~g} \text { gammalin/ha Yield } 632 \\
\mathrm{~kg} / \mathrm{ha} \text {. }\end{array}$ \\
\hline Farmers spray when money is available. & Spray from august to December missing November \\
\hline No spraying against blackpod, $111 \mathrm{~kg}$ dry beans. & $\begin{array}{l}\text { Spraying six times / year at monthly Intervals with } \\
\text { recommended fungicides plus all cultural practices. }\end{array}$ \\
\hline $\begin{array}{l}\text { Large heaps fermented in less than } 6 \text { days, turning } \\
\text { once or not at all. Gives poor quality beans with } \\
\text { high proportion of slaty and deep purple beans. }\end{array}$ & $\begin{array}{l}\text { Heap fermentation with turning every other day. Fer- } \\
\text { ment for } 4 \text { days in the case of small heaps, and } 6 \text { days } \\
\text { in the case of Large heaps and sun drying. }\end{array}$ \\
\hline
\end{tabular}

Source: Adomako, Halm and Amponsah (1995)

${ }^{2}$ Cocoa Research Institute of Ghana. See annex for list of key CRIG research recommendations. 
Table 5: FFS and Non-FFS farmers compared

\begin{tabular}{ccc}
\hline Criteria & FFS Farmers' (\%) & Non-FFS Farmers**(\%) \\
\hline Frequency of weeding & 1.4 & 12.6 \\
Once & 51.1 & 56.3 \\
Twice & 43.3 & 29.6 \\
Thrice & 4.3 & 1.5 \\
Four times & & \\
& & 87.4 \\
Spraying against capsids? & 88.7 & 11.9 \\
Yes & 11.3 & $218.92(215.71)$ \\
No & $192.08(288.10)$ & \\
Yield (kg/ha) & &
\end{tabular}

Source: Survey data. $* * \mathrm{~N}=135$. Figures in parentheses are standard deviations

nificant differences $(\mathrm{P}<0.05)$ were found between the two groups $(\mathrm{t}=0.873, \mathrm{P}=0.383)$. Using similar procedure, the study found no significant differences $(\mathrm{P}<0.05)$ between the groups in respect of their overall attitudinal disposition towards cocoa (attitude index) $(\mathrm{t}=$ $0.695, \mathrm{P}=0.444)$; and yield of dry cocoa beans per ha $(\mathrm{t}=0.73, \mathrm{P}=0.383$ (see table 5$)$.

However, highly significant differences were found between the groups in relation to their carrying out of field activities on their farms (frequency of weeding the farm). FFS farmers carried out more frequent weeding than non-FFS farmers $\left(\chi^{2}=21.31\right.$, df $\left.=4, P<0.001\right)$. Differences in terms of spraying the cocoa against capsids (mirids) were not significant $(\mathrm{P}<0.05)$ $\left(\chi^{2}=1.351, \mathrm{df}=4, \mathrm{P}=0.853\right)($ see table 3$)$.

\section{DISCUSSION}

This study found no significant difference between FFS and non-FFS farmers in terms of awareness, attitudinal disposition towards cocoa and yield. This is quite revealing and contradicts findings from the Kakum studies (Baah et al, 2003) where in all these aspects, FFS farmers showed significant advances over the others. Perhaps the Ashanti FFS is still quite young and need time for whatever skills and knowledge that the farmers have learnt to be translated into yield and other indicators. Nevertheless, the findings are in consonance with those of Tripp, Wijeratne and Piyadasa (2005) in their evaluation of an FFS project in Sri Lanka.

Farmers not participating in the FFS showed resentment towards their neighbours for not sharing what they have gained with them. One of the key principles of the FFS is that it is self propagating (Pontius et al., 2002). That is, from one FFS, several other emerge being started by earlier graduates. This is only possible if there was effective transmission of learning experience to other farmers. This study found very little evidence of horizontal farmer - to- farmer dissemination of information, knowledge and skills acquired within the social systems in the cocoa communities. This is quite worrying because FFS groups are expected to survive beyond project phases into viable community development groups (Pretty and Ward, 2001), and this would depend on how well the FFS groups interact into the larger social.

Despite these observations, the prospects of the FFS approach becoming a major force in the national cocoa extension strategy appear bright given the fact that $\mathrm{MOFA}^{3}$ has endorsed it

${ }^{3}$ Ministry of Food and Agriculture 
(Afreh-Nuamah, 1999) and CRIG, which develops technologies to support the cocoa industry has shown keen interest in its development providing technical backstopping for the STCP project. In addition, there has been increasing demand for training in the FFS format from farmers, extension agents and farmer organizations (such as Kuapa Kookoo Limited).

Nevertheless, experiences elsewhere (Tripp et al. 2005; Röling and van de Fliert, 1994) indicate that in many instances it has been difficult to scale up FFS beyond the project phase because 'FFS requirements of well-trained facilitators, season-long courses, and first- hand participation make the economics of scaling up problematic' (Tripp et al., 2005:1717). Such challenges readily come to the fore in the Ghanaian context given that MOFA is still faced with teething problems in handling cocoa extension. How do we scale up to cover all cocoa districts? Or should we be dependent on international and local development agencies for scaling up? How sustainable will such a position be? These are important questions that need to be addressed. Political will and institutional endorsement may not be enough. Long-term logistical and budgetary commitments are needed to implement more FFSs. The initial cost of an IPM / FFS programme is high in comparison with other extension methods (such as the T \& V system) largely because of the ToT ${ }^{4}$ sessions (Bruin and Meerman, 2001). For example, a season-long FFS in Zanzibar for rice comprising 13-15 sessions costs US \$ 500-800, excluding costs of vehicle purchase or maintenance. They contend that donor support at the beginning of the programme is essential and that once the FFS is established; it can propagate itself at lower cost and become sustainable. The fact that the startphase requires large infusion of funds may have serious implications for scaling up and sustainability.

\section{CONCLUSIONS}

The search for approaches to meet the information needs of different farmer categories is likely to continue as new challenges emerge. There is no doubt that however that no single approach is likely to suit the different farmers and their environments. Approaches that seek to empower farmers to become better managers of their farms and the environment are more likely to be useful than those which merely 'dish out' information to farmers.

The FFS has been widely adopted because it has worked in a wide range of institutional and environmental contexts. It offers a platform for creative learning, enhanced awareness and group interaction (Bruin and Meerman, 2001). Because of its underlying participatory norms it is increasingly being used to address other social, economic or technical issues. For instance, in Cambodia, the principles of FFSs are being used in a pilot project ('Farmer Life School') to strengthen the resilience of farming communities to HIV/ AIDS (Yech, 2003).

Farmer Field Schools may not be the ultimate solution in the search for 'ideal' extension strategy or approach. What perhaps sets the FFS apart from other extension approaches is that it has tended to empower farmers to make more informed decisions about their farm enterprise. As Bruin and Meerman (2001) indicated, the FFS should be used to complement other approaches that have the capacity to cater for the needs of individuals and farmer groups by responding to their concerns and needs. The FFS could be used countrywide in the Ghanaian cocoa sector as there is demand for it and the needed manpower may available; but this will require substantial commitment on the part of policy makers, extension and research institutions and farmers alike. What is needed, to quote Gallagher (2003:6), 'is a commitment to and faith in farmers' and facilitators' ability to learn locally and apply learning to local problems themselves'.

${ }^{4}$ Training of Trainers

170 Journal of Science and Technology, Vol. 27, No. 3, December 2007 


\section{ACKNOWLEDGEMENTS}

The author is grateful to the management of the Sustainable Tree Crops Programme (STCP), Kumasi for their assistance during the fieldwork. This paper is published by the permission of the Executive Director of CRIG.

\section{REFERENCES}

Adomako, D., Halm, B.J., and Amponsah, J.D. (1995). Summary of Innovations/ Recommended technologies for Cocoa, Coffee, Sheanut and Kola production and Current Research Activities. Tafo: Cocoa Research Institute.

Afreh-Nuamah, K. (1999). Integrated crop and pest management activities in Ghana: Prospects and constraints. Paper presented at the National Review Workshop on IPM in Ghana, Accra, 16-17 December, 1999, $11 \mathrm{pp}$.

Baah, F. (2001a). Farmer participatory approaches towards cocoa IPM implementation. In: J. Vos and P. Neuenschwander (eds). Proceedings of the West Africa Regional Cocoa IPM Workshop, Cotonou, Benin, Nov. 13-15, 2001, pp 30-38.

Baah, F. (2001b). Towards a pluralistic approach in extension services delivery to Ghanaian cocoa farmers. Journal of the Ghana Science Association, 4 (2): 78-82

Baah, F. (2003). Dissemination pathways for cocoa research results in Ghana: The potential role of the radio (Unpublished report on the radio broadcasts of CRIG), Tafo: Cocoa Research Institute of Ghana.

Baah, F., Osei-Bonsu, K., Afrifa, A.A., AfrehNuamah, K and Amoako-Gyedu, G. (2003). Farmer Field School as Extension Strategy in the Ghana Cocoa Industry: Prospects and Challenges. In: Proceedings, $14^{\text {th }}$ International Cocoa Research Conference, Accra, pp 1177-1183.
Biggs, S.D. (1984). Agricultural Research: A review of social science analysis. Discussion paper 115, School of Development Studies, University of East Anglia, Norwich.

Boahene, K. (1995). Innovation Adoption as a Socio-economic Process: The Case of the Ghanaian Cocoa Industry. Amsterdam: Thesis Publishers

Bruin, G.C.A and Meerman, F. (2001). New ways of developing agricultural technologies: the Zanzibar experience with participatory integrated pest management. Wageningen University/CTA, $167 \mathrm{pp}$.

Casley, D.J. and Kumar, K. (1988). The collection, analysis and use of monitoring and evaluation data. Washington D.C.: The World Bank.

Chambers, R. (1980). The small farmer is professional. Ceres 13 (2): 20-23.

Chambers, R. (1986). Normal professionalism, new paradigms and development. IDS Discussion paper No. 227, IDS, University of Sussex, Brighton.

Chambers, R and Ghildyal, B.P. (1985). Agricultural research for resource-poor farmers. The Farmer First and Last model. Agricultural Administration, 20:1-30.

COCOBOD (1995). Report on causes of decline in cocoa production and measures to revamp the industry. Accra: Ghana Cocoa Board (COCOBOD), 103 pp.

Donkor, M. A., Jones, A. P and Henderson, C.P. (1991). Survey to Quantify Adoption of Cocoa Production Technologies in Ghana, FSU Research Report 3, Tafo: Cocoa Research Institute of Ghana.

FAO/World Bank (1986). Draft report on Third Cocoa Project for Ghana. Ghana agricultural sector review. World Bank Report No. 5366GH, Washington D.C.: The World Bank.

Farrington, J. (1998). Organisational Roles in Farmer Participatory Research and Exten- 
sion: Lessons from the last decade. Natural Resource Perspectives 27, London: Overseas Development Institute, 4 pp.

Gallagher, K. (2003). Fundamental Elements of a Farmer Field School. Leisa, 19 (1): 5-6.

ISSER (2005). State of the Ghanaian Economy in 2004. Legon: Institute of Statistical, Social and Economic Research (ISSER), University of Ghana.

Jiggins, J. (1981). Farming Systems Research: New name for old habits or the key to increasing farm productivity? An exploration with reference to sub-Saharan Africa. Nairobi: The Ford Foundation, 16 pp.

Mangan, J and Mangan, M.S. (2003). FFS for tree crops. Leisa, 19 (1): $30-31$.

MASDAR (1998). Socio-economic study of cocoa farming in Ghana. Consultancy report, Accra: Ghana Cocoa Board/ MASDER International consultants.

Neuman, W. L. (2003). Social Research Methods: Qualitative and Quantitative Approaches ( $5^{\text {th }}$ Edition). Boston and New York: Allyn and Bacon

Okali, C., Sumberg, J and Farrington, J. (1994). Farmer Participatory Research. London: Intermediate Publications.

Osei-Bonsu, K., Baah, F., Afrifa, A.A., Amoako-Gyampah, G and Osei-wusu Y.B. (2003). The Status of Cocoa in the Agrarian System of Some Rural Communities Surrounding the Kakum Forest Reserve, Ghana. Proceedings of the $14^{\text {th }}$ International Cocoa Research Conference, Accra, pp 1017-1022.

Pontius, J., Dilts, R and Bartlett, A. (Eds) (2002). Ten Years of IPM Training in Asiafrom Farmer Field School to Community IPM. Bangkok: FAO.

Pretty, J.N. (1995). Regenerating Agriculture. London: Earthscan Publications Limited.

Pretty, J and Ward, H. (2001). Social capital and the environment. World Development, 29: 209-227.
Richards, P. (1986). What's wrong with farming systems research? Paper for the conference of the development studies association, University of East Anglia, 15-16 September, 1986

Röling, N. (1994). The Changing Role of Agricultural Extension. In: Agricultural Extension in Africa, Proceedings of an international workshop, Yaounde, Cameroon, pp 7-20.

Röling, N and van de Fliert, E. (1994). Transforming extension for sustainable agriculture: the case of integrated pest management pest management in rice in Indonesia. Agriculture and Human Values, $11(2 / 3)$ : 96-108.

Röling, N and Pretty, J.N. (1997). Extension's Role in Sustainable Agricultural Development. In: B.E. Swanson, R.P Bentz and A.J Sofranko (eds), Improving Agricultural Extension: A Reference Manual. Rome: FAO.

Simmonds, N. W. (1986). A short Review of Farming Systems Research in the Tropics. Experimental Agriculture, 22:1-13.

Sumberg, J and Okali, C. (1988). Farmers, onfarm research and the development of new technology. Experimental Agriculture, 24 (3): $333-342$.

Tripp, R., Wijeratne, $\mathrm{M}$ and Piyadasa, V.H. (2005). What should we expect from Farmer Field Schools? A Sri Lanka Case Study. World Development, 33 (10): 1705-1720.

Tripp, R. (1989). Farmer participation in Agricultural research: new directions or old problem? Discussion paper 256, IDS, university of Sussex, Brighton.

Van de Fliert, E. (2003). Recognizing a Climate for Sustainability: Extension Beyond Transfer of Technology. Australian Journal of Experimental Agriculture, 43, 29-36.

Van de Fliert, E., Pontius, J and Roling, N. (1995). Searching for strategies to replicate a successful extension approach: Training of IPM trainers in Indonesia. European Journal

172 Journal of Science and Technology, Vol. 27, No. 3, December 2007 
of Agricultural Education and Extension 1:41-63.

Wiggins, S. (1995). Farming systems Research and Farmer Participatory Research. A discussion paper presented to AERDD students, Reading University, October 1995, 9 pp.
Yech, P. (2003). Farmer Life Schools in Cambodia. Leisa, 19 (1): 11-12. 